\title{
ECONOMIC FACTORS IN THE PROCESS OF CALCULATION OF ANNUITIES IN BODILY INJURY COMPENSATION CLAIMS UNDER LIABILITY INSURANCE
}

\author{
Anna Jędrzychowska \\ Wrocław University of Economics, Wroclaw, Poland \\ e-mail: anna.jedrzychowska@ue.wroc.pl \\ ORCID: 0000-0002-3837-1734
}

\section{Ilona Kwiecień \\ Wrocław University of Economics, Wroclaw, Poland e-mail: ilona.kwiecien@ue.wroc.pl}

ORCID: 0000-0003-3382-9467

(C) 2019 Anna Jędrzychowska, Ilona Kwiecień

This is an open access article distributed under the Creative Commons Attribution-NonCommercial-NoDerivs license (http://creativecommons.org/licenses/by-nc-nd/3.0/)

DOI: 10.15611/fins.2019.1.02

JEL Classification: G22, G28, J17

\begin{abstract}
The article constitutes a legal and economic discussion of the economic factors which may and should be taken into account while calculating the benefits compensating the loss of income of the injured and of their families in case of death. The analyzed benefits are an important element of compensation of economic loss in personal injury cases where the compensation is the duty of the perpetrator (or the entity responsible for him/her) within the system based on tort liability. In light of the ubiquitous nature of TPL insurance, the payer is usually the insurance company liable under the granted guarantee. The scope of such cover results from the contract and/or legal acts. The subject calculation was based on an actuarial annuity which also takes into account the likelihood of the claimant and his/ her relatives living until the subsequent periodical payments. The applied calculation is of an illustrative nature with regard to the considerations of the relevant economic assumptions made at the time of loss calculation. The discussion carried out in the article concerns the size and value of the economic factors that can be used in this model.
\end{abstract}

Keywords: annuity, compensation, personal damage, time value of money.

\section{Introduction}

Indemnity for economic losses in bodily injury cases within the civil liability and insurance system seems to be relatively easily quantifiable. The initiative of the parties and court assessment are focused on evidence issues and the demonstration 
of an adequate causation. However, loss in the form of lost income (or revenue) very often looks into the future in comparison with the current assessment and therefore is variable in light of the professional life cycle of the claimant. It therefore may give rise to many problems because in fact we do not always, especially in the event of a serious damage to a person or the death of a relative, deal with a closed and known period. In the Polish civil law system, compensation of the lost income - for direct victims under Art. $444 \S 2$ of the Civil Code and indirectly affected under Art. 446 $\S 2$ of the Civil Code - in principle, takes the form of an annuity (periodical payment). In the opinion of the authors, this implies the need to take into account the economic factors which should be considered in the calculation. This need is implied by the need to take into account the so-called future loss and long-term compensation in combination with the dynamic nature of the loss including their sensitivity to such factors as change of life cycle, demography, change of the scope of needs, inflation and other macroeconomic factors. These economic factors are also important even more so where the capitalization of annuities to a lump sum is considered. Payment in lump sum form is allowed in the Polish tort law as an exception "for important reasons", "in particular when it facilitates preparation for a new profession" under Art. 447 of the Civil Code. However, recently on the Polish market such capitalization to a lump sum is often proposed to the injured by the insurance companies, which may result among others from the benefits of releasing reserves. For the aggrieved, however, some specific risks appears by capitalization - an appropriate period of further life subject to compensation and the investment risk (cf. [Kelly 2009, p. 25]).

The justifiability of the statement about the importance of the discussed issues may also be affected by the experience from other markets (detailed overview: [Jędrzychowska, Kwiecień 2013]). In Great Britain, since 1984 the calculation of the aforesaid benefits is supported by a system of guidelines, i.e. the Ogden tables, continually improved and discussed with stakeholders and actuaries [Kelly 2009]. The concept of the tables is based on factors called multipliers, which are used to determine the lump sum as the equivalent of the capitalized present value of future losses on an annual basis (net in the case of lost earnings and pensions). Multipliers are based on forecasts of future mortality rates in the United Kingdom and possibly also other discounting factors that influence mortality risk. In addition, due to the risk induced by capitalization for claimants as a result of the changes in the Damages Act (1996) of 2005, the UK has been obliged to consider the compensation of lost income in the form of periodic benefits instead of the basic lump sum rule [Kelly 2009, p. 25].

In the United States, experts in economics (actuarial) are appointed as standard procedure in court proceedings in which the loss of income is claimed. They advise on a case-by-case basis, and it is also emphasized that they relate to market, macroeconomic and labour market data to a greater extent than on the British market. The use of expert opinions in a lawsuit differs in individual jurisdictions, due to the differences in the legal framework. The principle is a capitalized payment - most 
states require, for example, discounting lost earnings to present values, however, in some states the discount can be compensated by the alleged increase in wages and costs. Only a few states regulate the discount rate [Word 2009]. The problem of calculating the loss of earning capacity has been also scientifically considered in Lewis's work [Lewis el al. 2002], in which an increasing annuity was proposed as appropriate. The problem of quantifying the loss of income is also the subject of scientific work, for example at the University of London and the Sir John Cass Business School [Butt, Haberman, Verral 2008].

Adequate compensation of lost income (revenue) is in the best interest of the claimants as well as the state and society at large because it ensures the financial security of the claimants and the families supported by them; it also safeguards the system against loss externalisation thus having an effect on the efficiency of the system based on civil liability and insurance, where the legislator is the authority determining who should bear the burden of loss (in the case of the perpetrator or compulsory TPL insurance) [Kwiecien 2010]. It also affects the efficiency of the transfer of risk under TPL liability by insuring it and in fact offers information on the actual risk level.

In following parts, the authors carry out an analysis of the effect of the selected factors including allowance compensating the loss of earnings - of individuals surviving bodily or health damage (Art. $444 \mathrm{sec} .2$ of the Civil Code) and the beneficiaries supported financially by the deceased (Art. $466 \mathrm{sec}$. 2). All calculations made in the article were provided to illustrate the importance of the careful selection of factors in the bodily injuries compensation calculations [more on the use of annuities in the process of determining the actuarial value of the damage side in: [Jędrzychowska, Poprawska 2016a; 2016b; Jędrzychowska 2017].

\section{Compensation of lost earnings of a surviving victim of an accident}

In the case of an individual who is temporarily unable to work, the term annuity is determined while individuals with a permanent disability are granted a lifetime allowance. It has to be emphasised that in Poland, compensatory allowances are granted in the amount which omits social security contributions. This gives rise to a problem linked with the accumulation of retirement pension capital and therefore the allowance should be granted for the whole life. In such a calculation, however, one should take into account the adequate replacement rates based on the situation in the country (according to OECD ${ }^{1}$ the replacement rate for Poland is 0.53 ) and in the calculation of the benefits for the "retirement" years reduce the benefit granted adequately. There are no obstacles in determining the benefit during the retirement pension period if it is assumed that were it not for the disability, the claimant would still be generating income.

\footnotetext{
1 https://data.oecd.org/pension/net-pension-replacement-rates.htm\#indicator-chart.
} 
The benefit under TPL should be each time reduced by the amount of benefit received by the claimant from the social insurance system (e.g. disability allowance). This gives rise to certain calculation problems because these social benefits are granted often on a temporary basis with an option to be extended. Therefore, the problem arises of how long a period should be taken into account in the calculation of the allowance granted under social insurance schemes. Also the issue related to protection under health insurance has to be raised.

Another issue is allowance taxation. In Art. $21 \mathrm{sec} .1$ item 4 of the Act of 26 July, 1991 on Personal Income (Journal of Laws no. 80, item 350 as amended), the legislator in principle tax exempts the "amounts received in connection with non-life and life/ personal insurance" (except for benefits for damage to property items connected with the economic activity and special sections of agricultural production). Non-life insurance also includes TPL insurance - this question is indisputable in insurance classification and in light of the claimant's right to act directly with respect to the insurer (actio directa, Art. $822 \S 4$ of the Civil Code), the claim is paid directly to the claimant and therefore it seems that he/she actually uses the exemption. The legislator does not impose any restriction on the insurance contract executed by the beneficiary. In light of the broad definition of the subject of exemption, i.e. as the "amount", subject to exemption should be all benefits including pensions linked with direct damage as well as lost profits (e.g. earnings), though with respect to the latter, different interpretations can be encountered.

In the direct calculation of the present value of annuity, the first key issue is to determine the basis for the benefit. In a situation where an individual who may present the evidence of earnings made in the past period (e.g. one year), it is possible to assume the net average remuneration as the calculation basis. Likewise, for individuals conducting a business activity and agricultural activity, net average income generated in the past may be adopted. There are, however, situations where an obvious interpretation is not possible, for example this is the case of a claimant in the productive age although unemployed. The unemployed status does not exclude the possibility of a compensatory benefit/allowance. In this situation the claimant may claim the above-mentioned benefit subject to that he/she offers evidence that in the normal course of events should he/she not suffer the injury, he/she would have started employment. Therefore, the real and practical possibility of the claimant starting employment within the limits of his/her skills, not a theoretical one should be taken into account. Given the circumstances, with regard to an individual without employment history should we assume as the basis the minimum wage in the economy (I ACa 104/15, I ACa 362/14 - there was such a lawsuit), while with regard to the individual with a previous employment record, e.g. should we use as the basis of income certificates from previous employers (I ACa 1023/15, I ACa 589/15)? Or perhaps in both situations, we should use average remuneration in the sector where the claimant was properly prepared to render work and had the relevant certificates. Of equal importance is the question of the claimant's income in a situation where he/ 
she undertook seasonal or commission jobs, or short-term contractual employment. Another issue is an allowance for an individual who never undertook any work in connection with running a household. Should we assume in this situation that the person has not lost his/her income or rather determine the value of the person's work for the household as the income of such a person?

Also essential is the matter of determining the basis for the allowance calculation in connection with the inability to work by the accident victim who at the time of the accident was a minor. In the legal literature, the following issue is emphasised: "a claim in connection with the loss of ability to work or reduced outlook for a prosperous future is not justifiable in the case of a person who at the time of issue of the allowance decision due to his or her age was unable to undertake any gainful employment in which case the court - while dismissing the allowance claim - has the duty to determine the defendant's liability for any damage arising in the future". From the economic point of view, it may be assumed that the period until the age of commencement of professional activity is not included in the calculation of the allowance amount, yet the payment has already been made (upon the granting of allowance). The allowance payment may also be delayed or as per the aforementioned ruling of the Supreme Court and the benefit calculation may be deferred to a later period; thus the claimant will have to make a claim at the time of potential entry into the labour market (which of course is a matter of agreement and requires an individual approach each time). It is also postulated in the subject matter literature that the allowance of the proper nature should also be the allowance in connection with the reduced prosperity prospect in the future determined on the basis of average salary unless there are grounds for consideration of particular circumstances, for example the specific talents of the beneficiary. While determining the present value of such an allowance (pension) the proper determination of the monthly instalments value is of key importance; this would rather have to refer to the present or future professional situation of the claimant and choice of the manner of the valorization of such an allowance. There is no unequivocal answer to the question of what kind of earnings a child would have lost who had never undertaken any gainful employment and sometimes had not even started education in a given specialisation. It can be indisputably assumed that the child lost his/her earnings at a minimum level. However, considering the situation in terms of the inclusion of market reality in the calculation, it would perhaps be more justifiable to assume the average salary in the national economy. Should this amount be influenced by the family and the educational level of parents? Other issues can also be raised: from what age should the child be regarded as losing income or what age to assume as the age of starting gainful employment?

Another important issue is allowance valorization. Due to its long-term temporal horizon, the calculations should no doubts take into account the loss of purchasing power of money. In practice usually when it comes to allowance valorization it takes place by way of a court decision (on demand), not automatically. Valorization is 
usually based on the inflation rate (I ACa 556/13, I C 773/12). This gives rise to certain issues. First, is the inflation rate a reliable element reflecting economic reality with respect to salaries? Would it not be more appropriate for valorization purposes to use the rate of salary increases in the total economy? If the basis for the allowance calculation is the minimum salary then perhaps it would be appropriate to assume as the indexing model this particular benefit. With regard to individuals conducting their own economic activity, it seems rational to assume indexing consistent with the GDP growth rate. Regardless of which index should constitute the basis for valorization, there is also one more question: which of its constituents to assume in order to prevent the use of the temporary increase of its value (e.g. hyperinflation). A good solution is assuming an average yearly value of such an index based on the ten years preceding the issue of the decision. This will allow to assume the value representing the index's change in time and also determine the indexing power at a level adequate for the Polish economy. For example, the so-calculated inflation rate for Poland for 2007-2016 was $2.17 \%$, GDP increased to $3.82 \%$, salary growth rate $3.29 \%$, while minimum wage indexing was $7.48 \%$ p.a.

The above-mentioned two calculation examples depict the foregoing considerations; the first example presents the differences in the present value of the actuarial annuity based on different assumptions with respect to the value of the first benefit payment and valorization ratio. The other will additionally show the time of granting life annuity to the person who is to be the beneficiary of the allowance due to loss of ability to work; the questions are whether the individual lost his/her income at the age of 18 or 25 , and which year to assume as the hypothetical moment of commencement of gainful employment. With respect to both annuities, an assumption was made that the benefit is paid once a year in advance (according to the structure of the Life Expectancy Tables). In order to discount the income flow, an average technical rate from the period 2007-2016 for Poland was taken into account, i.e. $3.09 \%$. Also used in the calculations was the value of the average salary in the national economy in 2016, i.e. PLN 2886 and the minimum salary in 2016, i.e. PLN 1850 . Other parameters were assumed at the level mentioned earlier in the text. The calculation is exclusive of social insurance benefit and other social benefits.

Example 1. As a consequence of a car accident, a 40-year-old male becomes permanently unable to undertake gainful employment. The present values of the calculated annuities are given in Figure 1. It was assumed that he would have undertaken employment up to the age of 70, after which time the benefit was reduced to a level corresponding to the replacement rate. The allowance was calculated on the basis of the average remuneration in the national economy (light grey bars from 1 to 3 ), or the minimum salary (dark grey bars from 4 to 6). The valorization was made at the inflation rate (bars 1 and 4), taking into account salary increases (bars 2 and 4), GDP growth rate (bar 3) as well as the minimum salary indexing (bar 6). 
1800000

1660508.30 PLN

1600000

1400000

1242351.99 PLN

1200000

1000000

800000

600000

400000

200000

943156.12 PLN

1133098.72 PLN

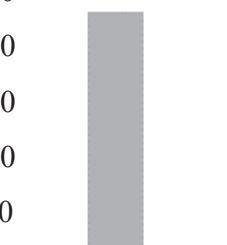

0

1
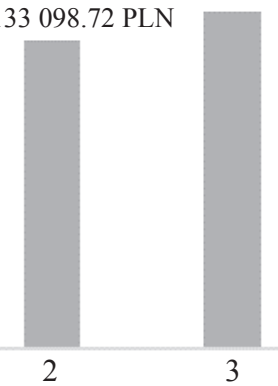

604 587.26 PLN

726345.33 PLN

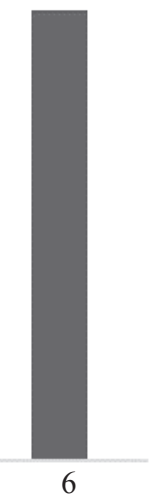

Fig. 1. Present values of annuities in connection with the lost income calculated for Example 1

Source: own calculations.

The first conclusions based on the illustration show that the current values of allowance are high and the differences derived from different assumptions may contribute to a multiplication of this amount. For example, the current value of the allowance based on the minimum salary in the economy differs only in the valorization rate from the level of c. PLN 600 thousand; taking into consideration the indexing consistent with the salary growth rate the value reaches over PLN 1.5 million.

Example 2. Due to a medical error, a 5-year-old boy lost completely his ability to work. It is assumed that he would have worked until the age of 70 . With respect to the annuity payment as above, a replacement rate was applied. The example shows the significance of what may happen when the child's age is assumed as the beginning of its professional activity. It was assumed that it would have been either the age of 18 (light grey bars), or 25 (dark grey bars) in Figure 2. Also shown are the differences in the present value of annuity with the different assumptions underlying the calculation basis of the benefit and valorization ratio. The first two values were obtained using the average salary in the economy and inflation valorization, the next two (3 and 4) also assume the average salary in the economy, yet are valorized against the salary increase rate. Bars 5 and 6 represent the calculations based on the minimum salary valorized against the inflation rate and the two final ones concerning the annuity based on the minimum salary valorized against the salary increase rate. 


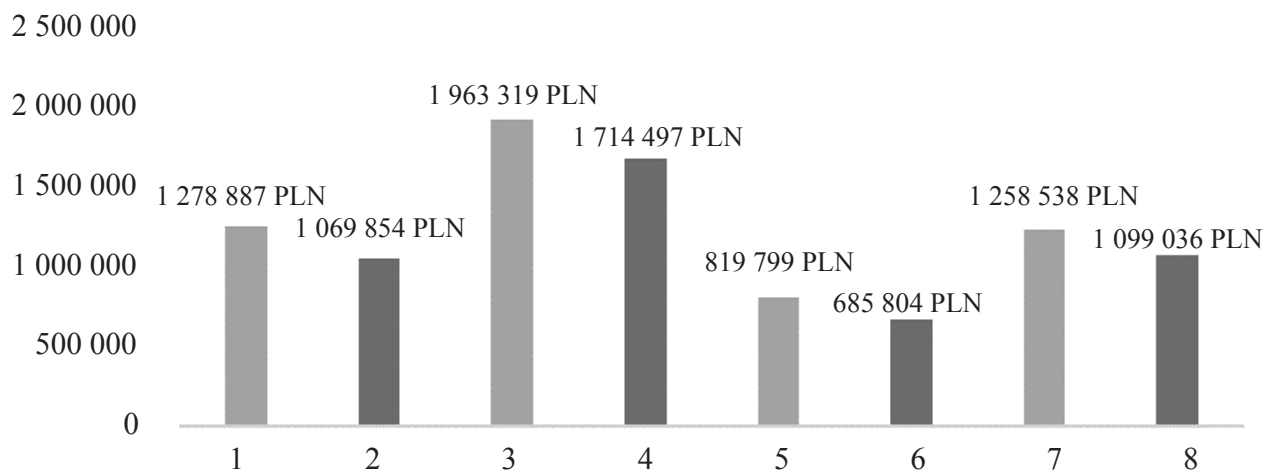

Fig. 2. Present values of annuities in connection with the lost income calculated for Example 2 Source: own materials.

The calculated values are higher than those calculated for Example 1 and derive from a longer period of annuity payment. What is however important in this illustration is the differences in results solely with regard to the hypothetical age of commencement of professional activity by the claimant. These values are c. $15-20 \%$ and account for the difference between the level of benefit starting at 18 in comparison with the benefit whose payment begins at the age of 25 . The difference in the age of commencement of professional activity may for example be a consequence of university education. It can therefore be assumed that the claimant who starts work at the age of 18 would receive a minimum wage (i.e. PV of PLN 819733.21 indexed against the inflation rate or PLN 1258853.57 indexed against the salary increase rate); the individual who would start gainful employment a little later, after graduation from studies, in theory might lose his/her revenue from the age of 25 but in the amount of average salary (therefore PV is PLN 1069 854.19 PL valorized against the inflation rate or PLN 1714496.68 PLN valorized against the salary increase rate).

It has to be emphasised that the granting of an annuity adequate to income lost by the accident victim, which will be paid for a lifetime, eliminates the risk linked with the loss of work. The risk of loss of work for professionally active people in Poland is considerable bearing in mind the unemployment rate of c. 8.5\% recorded in 2016. Determining the amount of annuity paid out in an accumulated amount (single time payment corresponding to the future periods for which it was determined) may pose a risk to both sides. It has to be emphasised that in contrast to the American market, the admissibility of allowance capitalization (lump sum) within the Polish civil law system is limited to very important reasons; in particular a situation where the victim has become a disabled person, and the granting of a single time benefit may contribute to his/her gaining new professional skills and the performance of a new 
profession (Art. 447 of the Civil Code). Awareness of what and how indexes affect the risk allows, in practice, both parties to properly assess their respective positions.

\section{Compensation of lost income for indirect victims}

Under Art. $446 \S 2$ of the Civil Code, individuals who were supported by the deceased paying alimony to them (optionally, also persons to whom the deceased provided such means on a voluntary basis, which however will remain outside the scope of this considerations) have the right to claim compensation with respect to lost income. The allowance has the form of a benefit paid in accordance with the needs of the victim and the possibilities of obtaining gainful employment and the property status of the deceased throughout the period of the likely duration of the alimony obligation.

To determine the value of the current allowance for the children, a definite time allowance can be used with respect to a child up to which the parent is required to support such a child financially (alimony). Example 3 is used to illustrate the importance of a child's age by which the allowance is determined. For spouses, it is assumed that the benefit is paid out throughout their lifetime.

In the process of the determination of the allowance, as in the previous examples, it is important to make adequate assumptions with respect to lost income and the manner of its valorization. At this point however new difficulties appear, namely what is the cost of own consumption of an accident victim, i.e. what level of their expenses they designate for their private purposes which the household in consequence of the victim's death would not bear. Research carried out by the authors shows that this depends on the size of the household. In household 2, which is run separately, it is c. $40 \%$, and the more populous the household, the more it decreases. It can be assumed as c. $25 \%$ for a child and $30-35 \%$ for an adult [Jędrzychowska, Pietrzyk, Rokita 2018]. However, Zakład Ubezpieczeń Społecznych (i.e. the institution in charge of benefits payment) when determining the family allowance assumes the costs of self-supporting of the deceased at the level of $10 \%$. The importance of this factor in determining the value of the allowance is presented in Example 4. Each member of the deceased's family is granted an equal part of his/her net income reduced by the own-consumption cost and benefits paid by the social security system.

Example 3. A 40-year-old man dies in a traffic accident. The beneficiaries entitled to receive allowances after the man's death are his wife - aged 35, and two daughters aged 3 and 6 . A simplification was assumed that the net income of the victim corresponded to the average salary in the national economy. Calculations are made in 4 options (presented in Figure 3): bars 1-4 correspond to the assumption that valorization is made at the inflation rate and the children receive the allowance until they are 18; other bars, 5-8, are calculated only based on the assumption that the children will receive the annuity until the age of 25 , the consecutive ones, i.e. 9-12, correspond to the assumption that valorization is made in accordance with the 
salary increase rate and the children will receive the allowance until the age of 18 , the subsequent ones, i.e. 13-16, are calculated with the changed assumption that the children will receive the allowance until the age of 25 . The consecutive bars in the series represent the following respectively: wife's allowance, allowance for the older child, allowance for the younger child and the total value. The calculations are made based on a $30 \%$ own consumption level of the deceased.

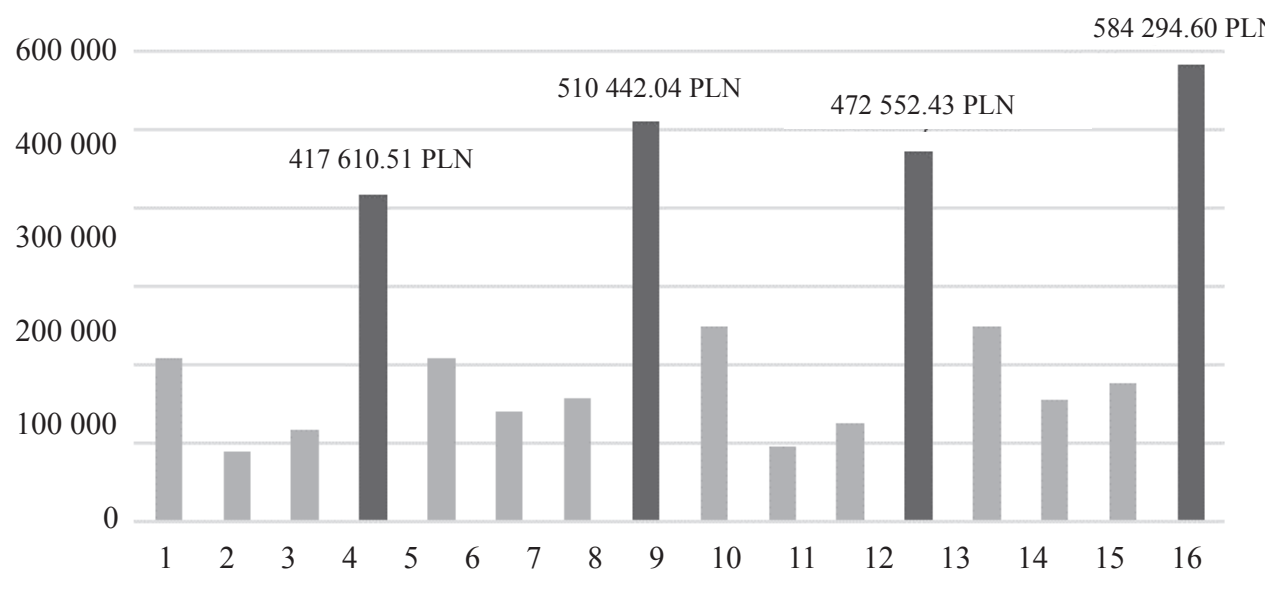

Fig. 3. Current values of allowances in connection with the lost income calculated for Example 3

Source: own calculations.

The calculated values show that here also the initial assumptions concerning the basis for the calculation of the annuity and its valorization were used. While comparing the present value of the annuity for the wife based on valorization against the inflation, and the value obtained by valorizing against the salary increase rate, the resulting value is PLN 39723.39 PLN, i.e. the present value of the annuity based on the second of the valorization ratios which is higher by c. $20 \%$. In the case of the two daughters, the differences are naturally less significant as these are term annuities. The differences range from $6 \%$ to $12 \%$ in favor of the valorization against the salary increase rate.

The example also illustrates the significance of the duration of the period of financial support of the children. Table 1 quotes the present values of annuities calculated for the three and six-year-old girls from Example 3. As you can see, the difference deriving from the extended payment period by seven years may result in an increase of the present value of annuity by over $50 \%$. 
Table 1. Present values of annuities in connection with the lost income for the deceased children calculation for Example 3

\begin{tabular}{|l|c|c|c|}
\hline \multicolumn{1}{|c|}{ Indexation } & \multicolumn{3}{c|}{ Salary growth rate inflation } \\
\hline Children & up to 18 & up to 25 & difference \\
\hline Older child & PLN 90 520.09 & PLN 141 804.05 & PLN 51 283.96 \\
\hline Younger child & PLN 117 221.23 & PLN 158 768.80 & PLN 41547.57 \\
\hline Indexation & \multicolumn{3}{|c|}{ Salary growth rate indexing } \\
\hline Children & up to 18 & up to 25 & difference \\
\hline Older child & PLN 96 015.28 & PLN 156 689.20 & PLN 60 673.92 \\
\hline Younger child & PLN 126 944.57 & PLN 178 012.80 & PLN 51 077.23 \\
\hline
\end{tabular}

Source: own materials.

In Example 4 we consider a family analogous to the one described in Example 3 adding one simplification, namely that the allowance is valorized against the inflation rate. This time the relevant variable is the level of costs linked with the own consumption of the deceased. Figure 4 quotes the present value of annuity calculated for the wife and two daughters assuming 10\% own consumption (light grey bar) and $30 \%$ (dark grey bar).

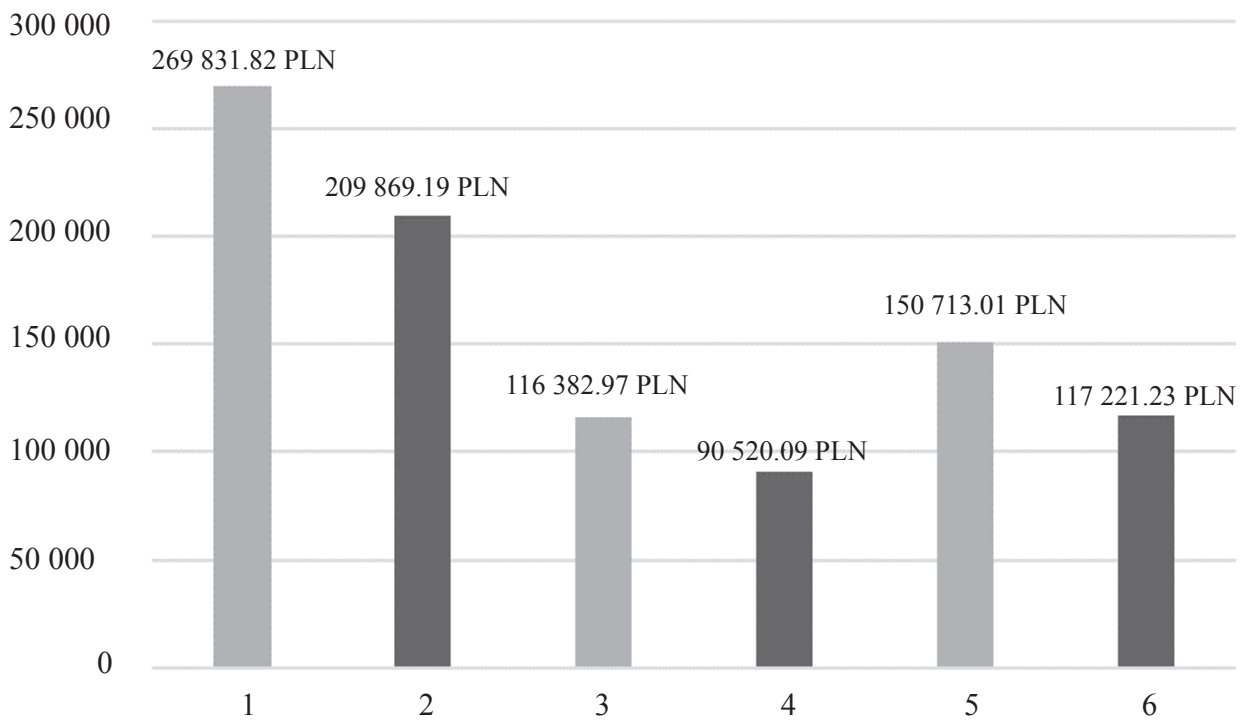

Fig. 4. Present values of annuities in connection with the lost income for the deceased children calculation for Example 4

Source: own calculations. 
In this case it is evident that the differences are considerable. For the wife they amount to c. PLN 69 thousand which is $20 \%$ of the lower benefit. For the older daughter the difference is about 25 thousand, And for the younger one about 45 thousand.

The above-presented calculations concern the way of determining the principal amount that will be paid out as an annuity. The presented ways of calculation of the present value on one side indicate the current costs linked with the future payments, and on the other also offer a picture of the so-called accumulated allowance which may be the subject of a claim. These calculations show the considerable influence of the following factors on the analysed benefit:

- assumed interest rate (benefit increase rate and principal amount value increase) - the assumption of a specified benefit increase rate may be an element of determining the automatic valorizing of the allowance based on the settlement, or court decision; it is obvious that the index level is of considerable importance and determines the level of the principal and reserve value for both parties involved - i.e. the payer and the beneficiary;

- assumed benefit amount constituting the basis for the calculation of the future income (two possible base values were assumed - minimum net salary in the economy, average net salary in the national economy);

- assumed deferred income flow taken into account at the stage of calculation of the current allowance - by taking into account the increase of salaries, inflation or the minimum salary indexing.

\section{Conclusion}

According to many studies concerning the insurance market in Europe, despite the drop in the number of traffic accidents and collisions (most important events generating claims under TPL) as well as the number of the injuries and fatalities, a decline in the claims linked with the injury to health or death cannot be observed [Monkiewicz, Monkiewicz (ed.) 2014; GenRe 2014; Insurance Europe 2016]. We observe on these markets an increase in the number of value of the claims in connection with personal injuries. Also, attention is drawn to the fact that in addition to the long-term care and benefits for the claims of a non-material nature, an important element contributing to the increase are the benefits in connection with the loss of revenue [Werwigk 2012]. This is a consequence of both demographic trends which are extended life expectancy and the period of professional activity, as well as of economic conditions, i.e. trends on financial markets and changes of ratios issued in benefit calculation, the growth of society's wealth and the crises in the labour mark including trends with respect to the influence of disability on professional activity, personal and professional life cycle.

The complexity of the factors determining the correct annuity determination and the need for subject matter support of the victims, coupled with the same time use of the 
compensation sources in the form of TPL insurance so as to avoid the externalisation of losses, necessitate giving thought to the creation of mechanisms supporting the benefit calculation process, perhaps following in the foot-steps of other countries. The current debate moderated by the Financial Ombudsman and the Financial Supervision Authority with respect to the standardisation of compensation (benefit) amounts in cases of personal injury, shows that such solutions are necessary. Also, one should make sure that a proper benefit calculations methodology is developed with respect to economic damage so that the related benefits are determined in consideration of economic mechanisms, human life cycle and the personal finances of the victim. Due to the stronger substantive position of the insurance company and its larger awareness of trends prevailing on the capital market, which probably converts into the possibility of using higher return rates within the framework of portfolio investments or diversification of investment risk, it can be assumed that the victim should be protected by the possibility of using expert opinion concerning the ratios used when determining the allowance amount.

\section{Bibliography}

Butt Z., Haberman S., Verral R., 2008, Calculating compensation for loss of future earnings: Estimating and using work life expectancy, Journal of the Royal Statistical Society, 37.

GenRe, 2014, A Comparison of Compensation for Personal Injury Claims in Europe, 2014, http:// www.genre.com/knowledge/publications/claimsfocus-pc-201309-en.html.

Insurance Europe, 2016, European Motor Insurance Markets, 2016, https://www.insuranceeurope.eu/ european-motor-insurance-markets.

Jędrzychowska A., 2017, Compensation for those indirectly affected by the death of a household member, Economics and Culture, 14(02), pp. 22-32.

Jędrzychowska A., Kwiecień I., 2013, Ekonomiczne aspekty kompensacji szkód osobowych o charakterze majątkowym na tle zagranicznych rozwiazań systemowych ze szczególnym uwzględnieniem problemu utraconych dochodów, Rozprawy Ubezpieczeniowe, Wyd. Rzecznik Ubezpieczeniowy, no. 14, pp. 5-27.

Jędrzychowska A., Pietrzyk R., Rokita P., 2018, Oszacowanie poziomu konsumpcji indywidualnej $i$ wspólnej w gospodarstwach domowych, Prace Naukowe Uniwersytetu Ekonomicznego we Wrocławiu, no. 31, pp. 56-65.

Jędrzychowska A., Poprawska E., 2016a, Analysis of the problem of determining loss of income and sources for their financing. The case of personal injuries caused in traffic accidents, Transformations in Business \& Economics, Kaunas Faculty of Humanities Vilnius University, vol. 15, no. 2A (38A), pp. 329-353.

Jędrzychowska A., Poprawska E., 2016b, Compensation for Income Lost - Long-term Effects on the Victim's Personal Finance, [in:] Krajíček J., Nesleha J., Urbanovsky K. (ed.), European Financial Systems 2016, Proceedings of the 13th International Scientific Conference, Masaryk University, ISBN 978-80-210-8308-0, pp. 276-284.

Kelly M., 2009, The development of an Actuarial Approach to the Calculation of Future Loss in the UK, [in:] Ward J.O., R.J. Thornton (ed.), Personal Injury and Wrongful Death Damages Calculations: Transatlantic Dialogue, Contemporary Studies in Economic and Financial Analysis, vol. 91 (2009). 
Kwiecień I., 2010, Czynniki determinujące skuteczność transferu ryzyka poniesienia ciężaru kompensacji szkód na osobie poprzez obowiązkowe ubezpieczenie odpowiedzialności cywilnej, Wiadomości Ubezpieczeniowe PIU, Warszawa, no. 4, pp. 5-28.

Lewis R., McNabb R., Robinson H., Wass V., 2002, Court award of damages for loss of future earnings: An empirical study and an alternative method of calculation, Journal of Law and Society, vol. 29 , no. 3 .

Monkiewicz J., Monkiewicz M. (ed.), 2016, Szkody osobowe z OC posiadaczy pojazdów mechanicznych $w$ Polsce $w$ okresie 2010-2015 w perspektywie europejskiej: podstawowe tendencje i problem, raport przygotowany na zlecenie Stowarzyszenia „ProMotor” przez Centrum Studiów Konsumenckich Wydziału Zarządzania Politechniki Warszawskiej.

Tinari F., Cahill K., Grivoyannis E., 2006, Did the 9/11 victim compensation fund accurately assess economic losses?, Topics in Economic Analysis \& Policy, vol. 6, issue 1 (January 2006), pp. 1-42, http:/www.tinarieconomics.com/sites/default/files/Victim\%20Compensation\%20Fund.pdf.

Werwigk U., 2012, Components of Bodily Injury Claims - A European Perspective, FIAR - International Insurance-Reinsurance Forum 2012, http://www.fiar.ro/downloads/2012/motor/swiss.pptx.

Ward O.J., 2009, Economic damages and tort reform: a comparative analysis of the calculation of economic damages in personal injury and death litigation in the United States and the United Kingdom.

www.data.oecd.org.

www.mortality.prg.

www.stat.gov.pl.

\section{CZYNNIKI EKONOMICZNE W USTALANIU ŚWIADCZEŃ RENTOWYCH W PROCESIE KOMPENSACJI SZKÓD NA OSOBIE Z UBEZPIECZEŃ OC}

Streszczenie: Artykuł stanowi prawno-ekonomiczną dyskusję nad czynnikami ekonomicznymi, które mogą i powinny być ujmowane w kalkulowaniu wysokości świadczenia z tytułu utraconych dochodów (dla poszkodowanego i jego bliskich). Analizowane świadczenia stanowią istotny element kompensacji szkody na osobie o charakterze majątkowym, do której kompensacji zobowiązany jest sprawca szkody (lub podmiot za niego odpowiedzialny) w systemie opartym na odpowiedzialności odszkodowawczej. Ze względu na powszechność ubezpieczenia ryzyka odpowiedzialności cywilnej płatnikiem jest często ubezpieczyciel, odpowiadający gwarancyjnie. Kalkulacja bazuje na rencie aktuarialnej, w której uwzględniono prawdopodobieństwo dożywania przez poszkodowanego oraz jego bliskich uprawnionych do kolejnych momentów wypłaty świadczeń. Zastosowana kalkulacja ma charakter ilustracyjny do podejmowanych rozważań nad istotnością czynionych przy ustalaniu wielkości szkody założeń ekonomicznych. Przeprowadzona w artykule dyskusja dotyczy zatem wielkości i wartości możliwych do wykorzystania w tym modelu wyceny czynników ekonomicznych.

Słowa kluczowe: renta, odszkodowanie, szkody na osobie, wartość pieniądza w czasie. 